\title{
The Impact of Human and Social Capital on the Employment of Haitian Immigrant Women in the U.S. Labor Force: A Comparative Analysis
}

\author{
Nadjhia N. Skakavac ${ }^{1}$ \\ ${ }^{1}$ Department of Sociology \& Criminal Justice, Virginia State University, Petersburg, VA, USA. \\ Correspondence: Nadjhia N. Skakavac, Department of Sociology \& Criminal Justice, Virginia State University, \\ Petersburg, VA., USA.
}

Received: February 12, 2016

Accepted: February 24, 2016

Available online: March 11, 2016

doi:10.11114/ijsss.v4i4.1369

URL: http://dx.doi.org/10.11114/ijsss.v4i4.1369

\begin{abstract}
Despite the emerging focus on women's migration and economic integration in the host countries, little is known about the participation of Haitian immigrant women in the U.S. labor force. This study examines the effects of nationality and mediating factors including human and social capital on the economic integration of Haitian women in the U.S. labor force. In order to better understand how Haitian women's economic integration differs from other immigrants from the Caribbean, their personal income, wage income and hours worked were compared with three other groups of immigrant women: Dominicans, Cubans and Jamaicans. This study relies on secondary data from the American Community Survey (ACS, 2007). ACS is a statistical program that was developed to replace the long form of the decennial census in 2010. The data are nationally representative as they represent all 50 states including District of Columbia, Puerto-Rico and all metropolitan areas. The sample size used was $(\mathrm{N}=3908)$ for Haitian women, $(\mathrm{N}=5540)$ for Dominicans, $(\mathrm{N}=5057)$ for Jamaicans and $(\mathrm{N}=8696)$ for Cubans. Findings indicated that the mean differences of Haitian women when compared to Cubans (-3.493), Dominicans (-1.248) and Jamaicans (-.544) were all negative. This implied that the other groups of women had better employment status than Haitian women. Moreover, since the difference was highest with the Cubans, it can also be drawn that Cubans have the best employment status among the groups.
\end{abstract}

Keywords: Haitian women, Caribbean women, U.S. labor force, immigrants, human- capital, social-capital

\section{Introduction}

The surge in international migration in recent years has led several researchers to focus on the labor participation of immigrants in the host country. The number of international migrants doubled between 1960 and 2004 and by 2005, more than 190 million people lived outside of their native country (Brauw, 2007). In the United States, this large movement of people from least developing countries is an evidence of the Hart-Cellar Immigration Act in 1965, which abolished restrictions on country quotas that severely limited immigration on people that were not of Western European origins (Lee, 2004; Levin, 2007).

The implication of the Hart-Cellar Immigration Act changed immigration laws from selecting immigrants on their countries of origin to welcoming new immigrants from any country who desired to reunite with family members already residing in the United States. These changes modified the United States immigration policy and, unintentionally, opened the way for a flow in immigration from Southern Europe, Asia and the Caribbean region (Borjas, \& Freeman, 1992; Keely, 1971). Since the 1965 Immigration Act was mostly favorable to family reunification, a myriad of women from different regions voluntarily traveled to the United States to join their husbands or male family members, who were the first to migrate prior to 1965 . Since then, such a net of feminization of migration practically represented 47 percent of all international migrants and nowadays, women migrants represent nearly 50 percent of that population (Zlotnik, 2003).

The flow of feminization of migration, led the Caribbean region to currently account for more than 50 percent of migrant women in the United States (Yinger, 2007). Such increased movement of women indicates that women from developing countries who migrate internationally do so in search of a better life. This flow of women, according to the United Nations International Research and Training Institute for the Advancement of Women (INSTRAW, 2007), has over the years produced different forms of female migration such as domestic workers and caregivers and the organized 
migration of women seeking political and economic freedom. Thus, within the subsequent decades, many women from the Caribbean region have, by and large, migrated independently in search for work rather as dependents of their husbands.

Despite the emerging focus on women's migration and their labor force participation in the host country in recent years, little is known about the employment of Haitian immigrant women in the United States. Since colonial times, Haiti has succumbed to multiple political atrocities that compelled Haitian women to emigrate in search for political freedom and a better life for themselves and the ones left behind. As Haiti became the first Black republic to end slavery by the French in 1804, the aftermath of the Haitian revolution followed by a legacy of violence during and after the Duvalier's regime, served as a major push factor for Haitian immigrant women. The political instability since then has led the country to gradually become one of the poorest in the Western Hemisphere. Consequently, as the pillars of the Haitian economy and as the head of households in most rural and urban communities, Haitian women with lower socioeconomic status are forced to leave behind the depleted economy of their home country in search for both economic and political freedom.

In this context, the purpose of this study is twofold. First, it examines factors influencing the employment of Haitian women in the United States labor force. These factors include human capital (nationality, English Proficiency, educational attainment,), social capital (length of residence, spouse's education and spouse's income), household factors (family composition and husband income) and structural factors (linguistic isolation, poverty, and citizenship status). Second, in an effort to better understand the impact of nationality on employment, the study compares Haitian women's employment and labor status with that of three other immigrant groups from (Jamaica, Cuba, and Dominican Republic). This comparison helps to examine the relationship between nationality and employment in the United States labor market. In this research, it is argued that despite the fact that the Jamaican, Haitian, Dominican and Cuban women migrate from the same Caribbean Region, they are not homogeneous and should not be treated as such. Cultural differences and particularly language of the home country set them apart as immigrants and as workers in the United States.

\section{Review of the Literature}

\subsection{Factors Influencing Immigrants' Employment}

Immigrants are frequently seen as economic actors motivated by the ambition and need to migrate in search for better economic conditions. A large body of the literature, therefore, examines their labor participation outcomes in the host country. However, despite the increased number of women in the labor market and their historically high rate of economic participation, less attention has been given to women immigrants in this milieu particularly in regards to Haitian women. Although half of the United States immigrant population is female, they are rarely seen as economic or political emigrants who are forced to migrate. Rather, they continue to be perceived as dependent of their husbands' wages or voluntary migrants seeking jobs.

A successful integration in the US labor force is contingent upon several factors including nationality, human capital and social capital of the immigrant. Nationality, as it can be expected, plays a significant role in immigrants' socioeconomic mobility in the host country. Immigrants who migrate from poorer countries to richer ones are more likely to face more difficulties in adjustment to the new culture than those who come from richer countries (Human Development Report, 2009). These difficulties include those encountered in the host country and those left behind in the country of origin including lack of experience in the industrialized market. Of the former, are sexual, racial and cultural discrimination including linguistic barriers that challenge their employment in the United States labor market; and of the latter, are the burdens of the impoverished conditions left behind in the home country. In addition to the limited skills they bring with them to the United States, immigrant women are also exposed to a dual problem of racism and sexism which may delay their entry to the labor market and marginalize them into dead-end jobs barely sufficient for their subsistence.

Immigrants who come from developing countries to the U.S. with a language barrier are at a disadvantage in the labor force (Borjas, 1994; Chiswick, 1978; Portes, \& Rumbaut, 1996). Not only do they have more difficulties finding jobs but they also earn significantly less than their native counterparts (Alba, \& Nee, 1999; Borjas, 1994). Linguistic isolation, due to lack of English fluency, minimizes their chances to have more contacts with natives as they remain concentrated in ethnic enclaves and thus receive less information on job opportunities (Aguilera, 2003; Sanders et al., 2002).

\subsection{Ethnic Inequalities}

Ethnic inequalities are sustained particularly in the labor force through the perception that immigrants from developing countries are less educated than the natives. This pertains particularly to Haitian immigrant women whose literacy rate 
in the home country is only at 57.3 percent (CIA - World Factbook, 2015). Thus, it can be assumed that their labor participation is delayed by lack of human and social capital when compared to that of natives since they are unable to "transfer" the skills acquired from the home country to the United States labor market (Borjas, 1994; Duleep, \& Regets, 1999). As noted by Friedberg (2000), immigrants' educational attainment and work experience acquired from the country of origin are disvalued in the host country. Although the racial/ethnic architecture in the United States subsumes Black ethnic groups within a homogeneous racial group, the differences that each immigrant group carries with them in the host country are unique to the country of origin.

In the United States, English remains the preeminent language of the American workforce. However, with a growing Hispanic population, the Spanish language has become the second most-common language in the country with more than 34 million people speaking Spanish as their primary language (American Community Survey, 2007). Within a larger context, although Haitian women share similar problems with other Caribbean female migrants, their experience in the host country can be more complicated. Unlike the Spanish and English speaking immigrants whose employment may be facilitated by their language ability in the United States, Haitian-Creole speaking immigrants face a different dilemma. The fact that they do not enter the country with the linguistic advantage of either English or Spanish, places them at a social distance from both natives and other immigrants in the United States.

Further, with the increasing transnational migration of ethnic groups that has changed the notion of race and ethnic relations between immigrants and native born in the United States labor force (Rogers, 2000; Waters, 1999), competition for cheap labor between natives and immigrants encourages wage inequality in the labor market. While US-born natives may refuse dead-end jobs, Haitian immigrant women may be more apt to accept those jobs for the sake of sending money back home to those left behind and whose subsistence depends solely on these remittances. In turn, this leads natives to perceive Haitians as a threat to their employment opportunities in the United States labor force.

\subsection{Human Capital}

The notion of human capital is centered on individualistic skills that the worker has acquired either through education or employment experiences. These skills rely on multiple factors that determine the economic position of the new worker in the labor market. The first is education, which, in most instances, is culturally biased in the sense that immigrants from developing countries have difficulties transferring their credentials to the host country (Zeng, \& Xie, 2004). It can therefore be assumed that in their search for work, Haitian women may earn lower pay if the employer does not recognize their educational qualifications as being equivalent to those acquired in the United States. On the contrary, education obtained in countries that are linguistically and culturally comparable to that of the host country receives full recognition in the hiring or promotional process of immigrant employees (Chiswick, \& Miller, 2002).

English fluency is essential for positive experience in the U.S. labor force. Based on the linguistic barrier that many Haitian women encounter upon entry in the United States, it can be argued that education received in the Anglo-Caribbean regions (Jamaica, Trinidad, Guyana) may be better valued by employers in the United States labor force than that received in Haiti. Further, because of the large increase of Hispanic immigrants in the United States, and considering Spanish is the second official language in the United States, the integration of Spanish speaking immigrants is facilitated by linguistic advantages when searching for work. Unsurprisingly, the lack of human capital that is reflective of Haitian women's negative experiences in the labor force is worsened while the chances of occupying a position of authority are also curtailed by language barriers.

In support to the effect of human capital on wage assimilation, it is argued that immigrants with low level of human capital are at a disadvantage in the labor force (Borjas, 1995). There are three important factors influencing the returns of the human capital hypothesis on employment. The first factor is education. Studies supporting the segmented hypothesis, have found that education obtained in the home country may have "insignificant value" in the host country. Bratsberg and Ragan (2000) find that immigrants, who have acquired their education in the US, have higher returns than those who have received their education in the home country. Waldinger and Felciano (2004) propose a perception of the US economic structure that yields a distinctive prediction that immigrants from developing countries are likely to be at risk to experience segmented assimilation or downward mobility since they are likely to experience structural barriers that hinder their life chances. The authors explain the experience of contemporary immigrants as a reflection of the American hourglass economy which demands of immigrants to either acquire higher education and to become part of the professional elite class or else, "accept the same menial jobs that their parents are likely to occupy."

The second factor is language. Immigration studies have noted that immigrants with a language barrier face greater challenges in their attempt to transfer their human capital to the host country (Friedberg, 2000; Zeng, \& Zie, 2004). With the exceptions of a few jobs, most jobs with higher earnings in the US labor force require knowledge in English (Chiswick, \& Miller, 2002).

The third factor is length of residence in the host country. While classical assimilation predicts longer length of 
residence in the U.S. as a relying factor leading to full convergence and upward mobility, segmented assimilation theorists have argued that in fact, the longer immigrants live in the host country, the more 'damaged' are their chances to fare socioeconomically well (Kao, \& Tienda, 1995). Similar to these authors, others have found that one key factor contributing to the 'damaging effect' of longer residence reflects the prevalence of single-parent headship among later generation immigrants who fully assimilate (Oropesa \& Landale 1997). The challenges they face in their process of economic integration and lack of capital that is deemed important to the labor market place them at a distance. Thus, according to Portes and Rumbaut and Portes (2001), immigrants with longer length of residence confront a segmented environment in which their career success is challenged by: (1) persistence of racial discrimination (2) bifurcation of the American labor market, and (3) consolidation of a marginalized population in the inner city.

Within the context of the segmented path hypothesis, recent immigrants who lack enough human capital and ethnic contacts, become vulnerable to the American socioeconomic system that pushes them to assimilate into a minority underclass (Portes, \& Rumbaut, 2001). In fear of not wanting to become part of the underclass, Black immigrants chose to de-assimilate and thus keeping minimum contact with Black American natives (Waldinger, \& Feliciano, 2004).

\subsection{Social Capital}

Considerable attention has been given to the role of social capital in the sociological literature of people's life chances (Bourdieu, 1986; Coleman, 1990; Ioannides, \& Loury, 2004; Portes 1998). These authors argued that social capital depends on the social network that one has independently acquired over time or ascribed through their socioeconomic background of their parents. It is assumed therefore, the better one's socioeconomic status, the more valuable are their contacts and the better are their resources to fare well in the opportunity structure of society.

Married women' household responsibilities may be decreased if their income surpasses their husbands; and even though the latter consequently become more engaged in the domestic chores of the household, they are likely to remind their wives of the traditional gender role (i.e., cleaning, cooking and take care of the children) (Bittman et al., 2003). Past research on women's employment show that children continue to reduce women's paid work in many ethnic groups (Cohen, \& Bianchi, 1999; Tienda et al., 1992). This may be because mothers, despite their marital status, are generally the one responsible to take care of their children when they are sick. Thus, the traditional gender role not only holds women responsible for the welfare of their children but also for that of their elderly parents (Singleton, 1998). While some studies have found that marriage may deter employment because husband's income may discourage employment, (Kahn, \& Whittington, 1996; Tienda, \& Glass, 1985), others have noted a positive correlation between marriage and employment for Black women (Christopher, 1996; Corcoran, 1999).

Very often, women struggle between finding work contingent to their domestic responsibilities; they become compelled to have fewer children by becoming more aware of their fertility rate (Cancian \& Reed, 2009). In addition to the stress associated with being a mother, a wife, the primary caregiver and a professional, women's socioeconomic mobility is impeded by gender stratification in the labor force. As noted by Hull and Nelson (2000), a woman's chance to be promoted as a partner of a high-powered position is generally minimized due to the negative effects that women encounter in trying to find equilibrium between home and work. As women, they are faced with the glass-ceiling that controls and challenges their potential to hold positions of authority; and as mothers and wives they frequently struggle between domestic chores and jobs' responsibilities. Further, their foreign status in the host country exposes them to xenophobic prejudices that frequently keep them at a social distance from natives.

Through the theoretical lenses of segmented assimilation, it is argued that immigrants rely on their contacts that have been established within an ethnic enclave to profit from valuable resources such as job information (Portes, Fernandez-Kelly, \& Haller, 2005). With their association with those who possess stronger social economic status, new immigrants not only receive information of where to look for jobs, but also how to present themselves to the employer to get the job, how to get the desired occupations and how to behave thereafter on the job so that they are not "let go" (Aguilera, \& Massey, 2003; Mouw, 2003).

On that same note, Portes, Kelly and Haller (2005), describes segmented assimilation as a "set of strategic outcomes in the lives of young second generation persons". These outcomes reflect a path of mobility which include (1) educational attainment, (2) occupation, (3) language use and preferences, and (4) employment; all of which reflect human and social capital of the immigrant. Given the limitation of this research data (ACS, 2007), on social network and ethnic ties, the study relies on the spouse's education and income to examine the effect of social capital on employment.

Length of residence is another measure predicting the economic mobility of immigrants. Women who have resided in the host country the longest have better opportunities in finding work (Becker, 1964; Borjas, 1987; Chiswick, 1978). The controversies on what factors influence earnings among immigrants, along with the lack of research on Caribbean immigrants and more specifically on Haitian immigrant women, paved the way for the contribution of the existing literature. 


\section{Theoretical Framework: Assimilation or Segmented?}

Proponents of the segmented assimilation model refute the one-sided analysis of classical assimilation and argue that there are multiple paths of assimilation to which immigrants experience upward mobility, while the structural hypothesis supports the notion that minority immigrants are challenged on the ground of race and ethnicity because structural barriers such as the spatial concentration into poor neighborhoods, cut off from access to educational attainment, employment and other opportunities (Park, \& Burgess, 1969; Rumbaut, \& Portes, 1993).

Contrary to classical assimilation, segmented assimilation relies on the notion that immigrants from later generations will experience multiple paths of assimilation that may hinder their integration into the dominant group. Despite their hindrances on the basis of social and structural barriers, new immigrants from second and third generations find different avenues to attain their goal, particularly by establishing strong ethnic ties without relying much on the resources of the dominant groups. In other words, according to the segmented assimilation perspective, assimilation or "Americanization" is no longer the path leading to socioeconomic mobility. Rather, immigrants from developing countries who do not assimilate are likely to prevent assimilating in the inner city way of life (Rumbaut, \& Portes, 2001).

The segmented assimilation theory places great emphasis on both micro and macro factors pertaining to the socioeconomic integration of contemporary migrants in the host country. Proponents of the segmented perspective assert that both human capital as well as social and structural factors affect how migrants in the host country fare in the opportunity structure of the U.S. labor market. They argue that immigrants from later generations are more likely to experience different paths of assimilation due to three main factors: (1) modes of reception (2) conditions of the host labor market, and (3) the quality of immigrant ethnic communities (Portes, \& Zhou, 1993; Zhou, \& Bankston, 1998). Studies explaining the effect of nationality and particularly ethnic inequality on employment, note that ethnic immigrants from developing countries, if employed, are likely to be concentrated in lower paying jobs (Alba, \& Nee, 2003 Borjas, 1994). Further, in the immigration literature, ethnic inequality reflects the role of human capital and social capital as structural factors that sustain income inequality among immigrants from different countries.

Proponents of the segmented assimilation theory have relied on these factors to posit that immigrants 'economic mobility is hindered by linguistic barriers that challenge their educational credentials obtained in the home country as transferable assets in the host country (Aguilera, 2003). Although the segmented assimilation theory provides important insights on the economic experience on immigrants, it nevertheless remains ambiguous and open to interpretation (Xie, \& Greenman, 2005). One of the reasons associated with such ambiguity is the broad perspective of the theory. As noted by Portes and Zhou (1993), segmented assimilation theory encompasses many interrelated components relevant to the experiences of new immigrants in the host country. Given the variability of immigrants' experiences in the host country, some researchers have argued that income may vary on the ground of human capital, social capital, and socioeconomic status (SES) and even gender (Farley, \& Alba, 2002; Waldinger, \& Feliciano, 2004).

Another important limitation of the segmented assimilation theory is its lack of focus on women. Although lack of human and social capital pose challenges to both men and women, the theory fails to pay particular attention to the household factors that particularly affect women as the primary caregiver (Galinsky, \& Bond, 1996). The study revealed that women's responsibilities at home decrease when they earn more than their husband. It can be assumed that women's traditional role as mothers and wives, home responsibilities may constrain their social capital and limit their social network to that of their husbands.

Other studies have noted that women entering the labor force are often those from lower economic status whose income is necessary as a contribution to support their families (Mishel, Bernstein, \& Allgretto, 2005). Household factors including children at home, traditional role as caregivers, spouse's insufficient income and possibly the need to care for the elderly, are important factors that affect the employment of women in the US labor market (Bittman et al., 2003). In an effort to refute the "one-size-fits-all" perspective of explaining gender inequality, few studies examining the experience of immigrants, have added "nationality" as an important variable on economic progress. However, despite the addition of nationality to the mix, little attention has been given to the experience of Caribbean immigrant women, particularly of Haitian immigrant women in the United States labor force. Considering that immigration to a foreign land often connotes the immigrants' "need" to assimilate into the host culture, the intersectionality of race, gender and class emphasized by the theories aforementioned are not sufficient to explain the cultural and social hindrances that women from developing countries endure during their economic process of integration in the United States labor force.

Thus, this study argues that despite the Anglo-Saxon ideology which promotes the importance of a straight line or complete acculturation for the attainment of economic mobility, differences in cultural capital including human capital as well as social and structural capital that are specific to the host country influence the immigrants' employment status and experience in the labor force. Also, in addition to the lack of capital that immigrants are likely to bring with them, 
as women, the gender factor makes their situation even more complicated.

Women in general share very similar types of discrimination in their search for work. However, in order to better understand the effect of nationality on employment in the United States, it is important to realize that not all women have the same experiences and the perception that the outside world has of them will vary not only based on their race and class but also on their country of origin and their accented English. In turn, high economic status in mainstream America is determined and even facilitated by capital that resembles that of the "middle class" (Flap, Kumcu, \& Bulder, 2000; Portes, 1998). Contrarily, for immigrant women, whose human capital diverges far from mainstream American culture, their economic integration is prone to be segmented and more likely to resemble that of the "underclass". This argument is relevant to the experience of Haitian women whose linguistic capital, Haitian-Creole, far differs from what is perceived as a valuable linguistic skill in the industrialized labor market of the United States.

\section{Data and Method}

The quantitative data for this study uses the American Community Survey as a secondary data. ACS is a statistical program that has been developed to replace the long form of the decennial census in 2010. Instead of collecting national surveys every ten years like the Census, ACS' data collection is continuous throughout the year and roll from January 1, 2007 through December 2007. The data are nationally representative as they represent all 50 states including the District of Columbia, Puerto Rico and all metropolitan areas with a population of more than 65,000 people. ACS employed three types of data collections: The mail out/mail back, Computer Assisted Telephone Interview (CATI) and the Computer Assisted Personal Interview (CAPI).

The analysis for this research is limited to the economically active Haitian women immigrants as well as women from Jamaica, Dominican Republic and Cuba in the US labor market who are between the age of 25 and 64 . The reason for the age selection is based on the assumption that people older than 24 have completed some forms of college education and are likely to be working full-time, and those older than 64 have retired. The data analysis of this research has two main focuses. The primary focus is on the employment of Haitian immigrant women, an understudied population in their participation in the United States labor force. The second is to compare Haitian women's employment with three other groups of women from the Caribbean: Jamaicans, (the largest Anglophone immigrant group from the Caribbean) Dominicans, (the largest Hispanophone group from the Caribbean) and Cuban women who have similar push factors with Haitians but have received better treatment as "refugees."

\subsection{Dependent Variable}

Employment is a dichotomous construct consisting of two forms of measures. The first measure is simply the yearly earning of the respondent. The second consists of three variables: number of weeks the respondent worked in the previous year, number of hours the person usually worked and the total wages earned.

\subsection{The Independent Variables}

Human Capital was measured by four indicators. The first is an ordinal measure of English proficiency whereby respondents were asked about their ability to speak English. It is ranked as: (1=very well, 2 well, $3=$ not well, $4=$ not at all). The second is educational attainment indicating an ordinal measure of: ( $0=$ Less than High School, $1=\mathrm{HS}, 2=$ Some College, 3=Associate Degree, 4=Bachelor's Degree, 5=Professional School Degree). The fourth is Marital Status and it is coded as a dummy variable: 1 for Married and 0 for Otherwise. Length of Residence will be measured by subtracting the year of when the survey was conducted to the year of the respondent's arrival. Length of US residence will be presented as the following: $1=0-9$ years, $2=10-19$ years, $3=20$ years and above.

\section{Results}

The study uses regression analysis to analyze the effects of all independent variables on the dependent variable (employment) which helps the researcher to estimate the conditional expectation of employment and to observe what variables account the most in influencing the dependent variable (employment).

Considering that least square regression is at least as good as any other method (Allison, 1999), in order to ensure a best structural modeling, the researcher ensured that a Best Linear Unbiased Estimates (BLUE) was produced. This means that the errors are expected to be zero and that the ordinary least square has a small variance of biases. As seen in Table 1 , the values for tolerances and VIF for each of the independent variables considered in this analysis do not violate multicollinearity assumption. This implies that the regression model developed could statistically predict the value of the total personal income. 
Table 1. Regression Model Coefficients for the Dependent Variable Total Personal Income

\begin{tabular}{|c|c|c|c|c|c|c|c|}
\hline \multirow[t]{2}{*}{ Model } & \multicolumn{2}{|c|}{$\begin{array}{l}\text { Unstandardized } \\
\text { Coefficients }\end{array}$} & \multirow{2}{*}{$\begin{array}{c}\text { Standardized } \\
\text { Coefficients } \\
\text { Beta }\end{array}$} & \multirow[b]{2}{*}{$\mathrm{t}$} & \multirow[b]{2}{*}{ Sig } & & \multirow{2}{*}{$\begin{array}{c}\text { Colliniearity } \\
\text { Statistics }\end{array}$} \\
\hline & B & Std. Error & & & & Tolerance & \\
\hline 11(Constant) & -16638.992 & 238.902 & & -69.65 & .000 & & \\
\hline $\begin{array}{l}\text { Total Family } \\
\text { Income }\end{array}$ & .801 & .001 & 1.849 & 1517.40 & .000 & .190 & 5.273 \\
\hline $\begin{array}{l}\text { Total Personal } \\
\text { Income }\end{array}$ & -.793 & .001 & -1.515 & -1335.95 & .000 & .219 & 4.568 \\
\hline $\begin{array}{c}\text { Educational } \\
\text { Attainment }\end{array}$ & 1784.460 & 17.900 & .069 & 99.69 & .000 & .582 & 1.719 \\
\hline $\begin{array}{l}\text { Language } \\
\text { Spoken }\end{array}$ & -.956 & .025 & -.027 & -37.79 & .000 & .537 & 1.861 \\
\hline $\begin{array}{l}\text { Linguistic } \\
\text { Isolation }\end{array}$ & 5146.442 & 120.373 & .026 & 42.75 & .000 & .733 & 1.363 \\
\hline $\begin{array}{l}\text { Citizenship } \\
\text { Status }\end{array}$ & -1328.351 & 41.397 & -.032 & -32.09 & .000 & .286 & 3.497 \\
\hline $\begin{array}{c}\text { Educational } \\
\text { Attainment } \\
\text { [of Spouse] }\end{array}$ & 429.388 & 16.507 & .018 & 26.01 & .000 & .584 & 1.711 \\
\hline $\begin{array}{l}\text { Number of } \\
\text { Families in } \\
\text { Household }\end{array}$ & -2374.048 & 110.728 & -.011 & -21.44 & .000 & .994 & 1.006 \\
\hline $\begin{array}{l}\text { Speaks } \\
\text { English }\end{array}$ & -480.971 & 34.102 & -.009 & -14.10 & .000 & .638 & 1.567 \\
\hline $\begin{array}{c}\text { Years of } \\
\text { Immigration }\end{array}$ & 1.252 & .102 & .011 & 12.33 & .000 & .360 & 2.777 \\
\hline Poverty Status & .445 & .184 & .002 & 2.42 & .015 & .591 & 1.691 \\
\hline
\end{tabular}

$* p<.05, * * p<.01$

\subsection{Testing the Hypotheses}

H1: The employment gap between Haitian women and Cuban women will be larger than that of the other groups (Jamaican and Dominican women).

In order to compare the Haitian women's employment with three other groups of women from the Caribbean namely the Jamaicans, the Dominicans and the Cubans, an analysis of variance between groups was used. This allows a comparison of means between the groups of women to determine which one of these women has better employment status. A Tukey Post-hoc test will be employed if there is indeed a significant difference between the groups to determine which among the groups have better employment status. The ANOVA table is presented in Table 2. It can be observed that there is a significant difference between the employment status of the groups of women ( $\mathrm{F}=160.472$, $\mathrm{p}$-value $=.000$ ). 
Table 2. Analysis of Variance (ANOVA) Comparison of Means for Employment Statuses of Groups

\begin{tabular}{|c|c|c|c|c|c|}
\hline & Sum of Square & $\mathrm{df}$ & Means Square & $\mathrm{F}$ & Sig \\
\hline Between Groups & 47135.339 & 3 & 15712.113 & 160.472 & .000 \\
\hline Within Groups & 2271255.395 & 23197 & 97.912 & --- & --- \\
\hline Total & 2318391.734 & 23200 & --- & --- & --- \\
\hline \multicolumn{6}{|c|}{ Employment Measures for Marital Status } \\
\hline $\begin{array}{l}\text { Income Between } \\
\text { Groups }\end{array}$ & $1.531 \mathrm{E} 17$ & 5 & $3.062 \mathrm{E} 16$ & 312420.899 & .000 \\
\hline $\begin{array}{lr}\text { Usual } & \text { Hours } \\
\text { Worked } & \text { Per } \\
\text { Week } & \end{array}$ & $2.246 \mathrm{E} 8$ & 5 & 4.492E7 & 116866.910 & .000 \\
\hline Wage and Salary & $1.854 \mathrm{E} 17$ & 5 & 3.709E16.726 & 382385.726 & .000 \\
\hline $\begin{array}{l}\text { Poverty Status } \\
\text { Between Groups }\end{array}$ & 2.088E7 & 3 & 6959110.749 & 278.514 & .000 \\
\hline
\end{tabular}

$* * p<.01$

Followed by the ANOVA comparison of means illustrated in Table 2, a Tukey post-hoc test was employed to determine which among the groups of women had the highest score for the employment status. The Tukey Post-hoc test is presented in Table 3 below. The structure of the table shows the mean difference between Haitian and Cubans (-3.493), Dominicans (-1.248) and Jamaicans (-.544). It can be observed that all the mean differences are negative which implies that the scores of Haitian women are lower than the other three women groups. Thus, it can be concluded from this analysis that the other women groups have better employment status than Haitian women. Moreover, since the difference is highest with the Cubans, it can also be drawn that Cubans have the best employment status among the groups. This is followed by the Dominicans then by the Jamaicans.

Table 3. Tukey Post-hoc Test for Comparison of Means in Employment of Women Groups

\begin{tabular}{|c|c|c|c|c|c|c|}
\hline \multirow{2}{*}{$\begin{array}{l}\text { Recoded Birth } \\
\text { Place bpld }\end{array}$} & \multirow{2}{*}{$\begin{array}{l}\text { Recoded Birth } \\
\text { Place bpld }\end{array}$} & \multirow{2}{*}{$\begin{array}{l}\text { Mean } \\
\text { Difference }\end{array}$} & \multirow[b]{2}{*}{ Std. Error } & \multirow[b]{2}{*}{ Sig. } & \multicolumn{2}{|c|}{$95 \%$ Confidence Interval } \\
\hline & & & & & Lower bound & Upper bound \\
\hline \multirow[t]{4}{*}{ Haiti } & Cuba & $-3.493^{*}$ & 0.191 & 0 & -3.98 & -3 \\
\hline & Dominican & $-1.248 *$ & 0.207 & 0 & -1.78 & -0.72 \\
\hline & Republic & & & & & \\
\hline & Jamaica & $-.544 *$ & 0.211 & 0.049 & -1.78 & -0.72 \\
\hline \multirow[t]{4}{*}{ Cuba } & Haiti & $3.493^{*}$ & 0.191 & 0 & 3 & 3.98 \\
\hline & Dominican & $2.245^{*}$ & 0.17 & 0 & 1.81 & 2.68 \\
\hline & Republic & & & & & \\
\hline & Jamaica & 2.950 & 0.175 & 0 & 2.5 & 3.4 \\
\hline Dominican & Haiti & $1.248^{*}$ & 0.207 & 0 & 0.72 & 1.78 \\
\hline \multicolumn{7}{|l|}{ Republic } \\
\hline & Cuba & $-2.245^{*}$ & 0.17 & 0 & -2.68 & -1.81 \\
\hline & Jamaica & $.705^{*}$ & 0.192 & 0.001 & 0.21 & 1.2 \\
\hline Jamaica & Haiti & $.544^{*}$ & 0.211 & 0.049 & 0 & -021 \\
\hline
\end{tabular}

H2: Haitian immigrant women with longer length of residence will fare significantly worse than those with shorter length of residence.

Pearson's $r$ Correlation analysis was used to determine whether the length of residence has an effect on the employment 
measures of Haiti immigrant women. In Table 4, it can be observed that the length of residence is significantly correlated with the employment measures of Haiti immigrant women. A negative correlation would mean that as the length of residence increases, the less the employment measure is. On the other hand, a positive correlation means that as the length of residence increase, the more the employment measure is.

As seen in Table 4, the total personal income (Pearson's $r=-.139$, p-value=.000) and the wage and salary income (Pearson's $\mathrm{r}=-.141$, p-value $=.000$ ) is negatively correlated with the years of immigration while the usual hours per week (Pearson's $r=.093$, p-value $=.000$ ) is positively correlated with the years of immigration. This implies that as the length of residence increases, the total personal income and wage and salary income decreases while the usual hours worked per week increases. Thus, Haitian immigrant women with longer length of residence will fare significantly worse than those with shorter length of residence.

H3: Increase in educational attainment will be associated with an increase in wage income for Haitian immigrant women in the United States.

Table 4 presents the correlation matrix of the wage income and the educational attainment of participants (Pearson's $\mathrm{r}=-.810$, $\mathrm{p}$-value=.000). A negative correlation could be observed between these variables as indicated by the negative values in the table. Thus, this implies that an increase in educational attainment results to a decrease in wage income.

H4: Significant other's income will positively correlate with Haitian women's

Income leads to an increase of income for Haitian women.

For the association between the income of participants and their spouse, a correlation analysis was conducted. In Table 4 , it can be observed that there is a significant positive relationship between these variables (Pearson's $r=.018$, $\mathrm{p}$-value $=.000)$. Thus, it can be concluded that as the income of participants increases, the income of their spouses would also increase. This invalidates the hypothesis that an increase in the significant other's income will lead to a decrease of income for Haitian women.

Table 4. Correlation Matrix of Income, Residence, Educational Attainment, and Employment Measures

\begin{tabular}{cccccccc}
\hline Personal & Wage and & Residence & Education & Hours & Spouse & Spouse \\
Income & Salary & & & Education & Income \\
\hline
\end{tabular}

Total Personal income

Wage and Salary Income

Length of Residence

$-.139 * *$

$-.141 * *$

Educational Attainment

$-810^{* *}$

Usual Hours Worked per

Week

$093 * *$

Educational Attainment of

Spouse

$.018 * *$

Total Personal Income of

Spouse

$* p<.05, * * p<.01$ (two-tailed tests)

\section{Discussion and Conclusion}

The present study concerns the employment characteristics of Haitian immigrant women in comparison to the employment of other Caribbean immigrant women (Dominican, Jamaican and Cuban) in the U.S. Labor force. Multiple Regression Analysis (MANOVA), Analysis of Variance (ANOVA) and Correlation Matrix were used to analyze the impact of both human and social capital on the employment for Haitian immigrant women and the comparative group. Results of this study on the employment gap between Haitian women and their counterparts indicate a larger gap in employment between Haitian and Cuban women. A relevant explanation of this finding reflects ethnic discrimination 
on the grounds of both race and ethnic inequality in the host country. These barriers as noted by experts in the field reveal that poor representation in the labor force is based on constant racism and discrimination that not only affect immigrants' self-perception but also their economic mobility (Waters, 1999).

Ethnicity was explored as a potential factor in employment status in the sample. MANOVA was conducted to determine whether the indicators of employment status varied across ethnicity in the sample. In general Haitian women have lower employment status than the rest of the group. Respectively, Cubans, Dominicans and Jamaicans have the highest level of employment status. This is observed despite Haitian women's larger portion of labor participation in the sample. Such findings may be explained by cultural representation of the group. It is possible that the growing acceptance of Hispanics in the country helps to explain the Cubans and Dominicans' higher employment status; whereas Haitians and Jamaicans' association with blackness and marginalization may have contributed to some challenges in their employment statuses. Although this current study did not account for racial differences, however, given the privileges of whiteness in the United States and considering that 65 percent of the Cuban population is White, with only 10 percent Black and 24 percent of mixed race (Pedraza, 2007), may very much explain their more favorable position in the labor force particularly when compared with Haitians of whom 95 percent of the population is Black. This explanation is further justified by empirical findings showing that the average income of Black Cuban immigrants is 40 percent less than their White counterparts (Garcia, 1996).

It is also important to note that although the goal of the Cuban Revolution of 1959 was to eliminate all forms of racial prejudice, the residual effect of racial discrimination prior to the revolution permitted the elite class, mostly White, to migrate with stronger human capital, such as wealth and higher educational credentials that are transferable in the United States' labor force. As predicted by the segmented assimilation theory, the economic well-being of immigrants in the host country depends on their race, ethnic background, human and social capital. This divergent trend can be seen in the dissimilar experience of Haitian Women. While Cuban women are a more desired group of migrants, their experiences in the host country are facilitated by a supportive Hispanic community and sustained by white supremacy. On the other hand, most Haitian women migrate with barely any resources that are necessary for their socio-economic mobility (Portes and Zhou, 1994).

For the effect of language spoken at home, correlations were obtained between English proficiency, length of residence and employment status. Base on the MANOVA results, Haitian women who spoke English at home, had higher levels of employment status. The correlation results between length of residence and employment status indicate a weak relationship and are negatively correlated with total personal income. In contrast, length of residence in the U.S. is positively associated with working hours. This shows that workers with longer residence work longer hours for less pay which supports the segmented assimilation theory. The findings show extra hours worked by Haitian women contributed to total family income in the sample. There are also a number of factors as predictors of a higher number of working hours among Haitian women in the study. For instance, for each higher level of educational attainment, Haitian women worked nearly two extra hours. This may represent the nature of work available to respondents whose income is not sufficient to make ends-meet. Consequently, they work longer hours to have the overtime pay rate.

Also, linguistic isolation contributed nearly $\$ 4,000$ additional wage and salary income among Haitian women in the sample. This finding appears rather unusual at face value but can be explained using the propositions that linguistic isolation was indirectly measured through urban location among the Haitian women in the study. It therefore appears that Haitian women earn more wage and salary income by virtue of being located in an urban setting with access to either more jobs or to higher paying jobs. Consequently, it is not linguistic isolation per se that predicts their higher wage and salary income but rather their concomitant location in the urban setting. Results of an independent t-test showed households where Spanish or English is the primary language have higher total incomes than households in which Haitian-Creole is spoken. This provides more evidence in favor of better economic status when English is spoken at home.

This study hopes to encourage more qualitative research on the social and cultural effects on immigrant women's labor participation in the host country. Results of this present study show human and social capital as good predictors of income. Specifically, educational attainment, speaking English at home and urban location play a significant role in employment status in the sample. Surprisingly, while English and Spanish households are associated with a higher income than Haitian-Creole speaking households, there is a fairly weak correlation between citizenship status and higher income. As this research has shown, the intersectionality of race, class and gender continues to play an important role in the socioeconomic integration of immigrant workers in the host country. Cultural marginality and the privilege of whiteness continue to persist. Perhaps qualitative research can provide better results in clarifying the socioeconomic welfare of Haitian immigrant women in the American labor force.

\section{References}


Aguilera, M. B. (2003). "The impact of the worker: How social capital influence the job tenure of formerly undocumented Mexican immigrants.” Sociological Inquiry, 73(1), 52-83. http://dx.doi.org/10.1111/1475-682X.00041

Aguilera, M. B., \& Massey, D. S. (2003). "Social capital and wages of Mexican migrants: New hypotheses and tests." Social Forces, 82(2), 671-701. http://dx.doi.org/10.1353/sof.2004.0001

Alba, R., \& Nee, V. (2003). Remaking the American Mainstream: Assimilation and Contemporary Immigration. USA: First Harvard University Press. http://dx.doi.org/10.4159/9780674020115

American Community Survey (2007). About the Data (Methodology): Papers, Presentations and Webinars. Retrieved from: http://www.census.gov/acs/www/AdvMeth/

Becker, G. S. (1964). Human capital: A theoretical and empirical analysis with special reference to education. Chicago: University of Chicago Press

Bittman, M., England, P., Sayer, L., Folbre, N., \& Matheson, G. (2003) "When does gender trump money? Bargaining and time in household work." American Journal of Sociology, 109, 186-214. http://dx.doi.org/10.1086/378341

Borjas, G. J. (1994). "The economics of immigration.” Journal of Economic Literature, 32, 1667-717.

Borjas, G. J. (1995). "Assimilation and changes in cohort quality revisited: What happened to immigrant earnings in the 1980's?" Journal of Labor Economics, 13(2) 201-45. http://dx.doi.org/10.1086/298373

Borjas, G. J., \& Freeman, R. B. (1992). Immigration and the Work Force. Chicago: The University of Chicago Press.

Bourdieu, P. (1986). The forms of capital: Handbook of theory and research for the sociology of education. NY: Greenwood Press. http://dx.doi.org/10.7208/chicago/9780226066707.001.0001

Bratsberg, B., \& Ragan, J. F. (2002). The Impact of Host Country Schooling on Earnings-A Study of Male Immigrants in the United States. Journal of Human Resources, 37(1), 63-105. http://dx.doi.org/10.2307/3069604

Brauw, A.D. (2007). International Migration: Can It Improve Standards among Poor and Vulnerable Populations? 2020 Focus Brief on the World's Poor and Hungry People. Washington, DC: IFRI.

Cancian, M., \& Reed, D. (2009). Family Structure, Childbearing and Parental Employment, Implications for the level and trend in Poverty, 26(2).

Chiswick, B. R. (1978). "The effect of Americanization on the earnings of foreign-born men.”, The Journal of Political Economy, 86, 897-922. http://dx.doi.org/10.1086/260717

Chiswick, B. R., \& Miller, P. W. (2002). Immigrant earnings: Language skills, linguistic concentrations and the business cycle. Journal of Population Economics, 15, 31-57. http://dx.doi.org/10.1007/PL00003838

Christopher, K. (1996). "Explaining the recent employment gap between Black and White women.” Sociological Focus, 29(3), 263-280. http://dx.doi.org/10.1080/00380237.1996.10570644

CIA-The World Factbook, (2015). Field Listing: Literacy. Retrieved from: https://www.cia.gov/library/publications/the-world-factbook/geos/ha.html

Cohen, P. N., \& Bianchi, S. M. (1999). "Marriage, children, and women's employment: What do we know?" Monthly Labor Review, 122(12), 22-31.

Coleman, J. S. (1990). Foundations of social theory. Cambridge, MA: Harvard University Press.

Corcoran, M. (1999). Black women's economic progress in race, gender, and economic inequality: African- American and Latina women in the labor market. NY: Russell Sage.

Duleep, H. O., \& Regets, M. C. (1999). Immigrants and Human- Capital Investment. American Economic Review, 89, 186- 72. http://dx.doi.org/10.1257/aer.89.2.186

Farley, R., \& Alba, R. (2002). The New Second Generation in the United States. International Migration Review, 36(3), 669-701. http://dx.doi.org/10.1111/j.1747-7379.2002.tb00100.x

Flap, H., Kumca, A., \& Bulder, B. (2000) "Social capital and business success.” In Rath, J. (Ed.), Immigrant Businesses: The Economic, Political, and Social Environment, Macmillan, London, 142-61.

Friedberg, R. M. (2000). You Can't Take It with You? Immigrant Assimilation and the Portability of Human Capital. Journal of Labor Economics, 18, 221- 51. http://dx.doi.org/10.1086/209957

Galinsky, E., Bond, J. T., \& Friedman, D. E. (1996). The Role of Employers in Addressing the Needs of Employed Parents. Journal of Social Issues, 52, 111-136. http://dx.doi.org/10.1111/j.1540-4560.1996.tb01582.x

Garcia, M. C. (1996). Havana USA: Cuban Exiles and Cuban-Americans in South Florida, 1959-1994. Berkeley: 
University of California Press.

Hull, K., \& Nelson, R. (2000). "Assimilation, choice, or constraint? Testing theories of gender differences in the careers of lawyers.” Social Forces, 79(1), 229-264. http://dx.doi.org/10.1093/sf/79.1.229

Human Development Report (HDR, 2009). Overcoming Barriers: Human Mobility and Development. Retrieved from http://hdr.undp.org/en/media/HDR-2009-EnSummary.

INSTRAW. (2007). International Research and Training Institute for the Advancement of Feminization of Migration.

Ioannides, Y. M., \& Loury, L. D. (2004). "Job information networks, neighborhood effects, and Income Inequality", Journal of Economic Literature, 92, 1056-1093. http://dx.doi.org/10.1257/0022051043004595

Kahn, J. R., \& Whittington, L. A. (1996). The labor supply of Latinas in the U.S.A: Comparing labor force participation, wages, and hours worked with Anglo and Black women." Population Research and Policy Review, 15, 45-73. http://dx.doi.org/10.1007/BF00156742

Kao, G., \& Tienda, M. (1995). “Optimism and Achievement: The Educational Performance of Immigrant Youth.” Social Science Quarterly, 76(1), 1-9.

Keely, C.B. (1971). "Effects of the Immigration Act of 1965 on selected population characteristics of immigrants to the United States. " Demography, 8(2), 157-169. http://dx.doi.org/10.2307/2060606

Lee, E. (2004). "Immigration and America's golden door." Reviews in American History, 32(1), 68-75. http://dx.doi.org/10.1353/rah.2004.0008

Mishel, L., Bernstein J., \& Allegretto, S. (2007). The State of Working America. Ithaca, NY: Cornell University Press.

Mouw, T. (2003). "Social capital and finding a job: Do contacts matter?” American Sociological Review, 68, 868-898. http://dx.doi.org/10.2307/1519749

Oropesa, R. S., \& Landale, S. (1997). In Search of the New Second Generation: Alternative Strategies for Identifying Second Generation Children and Understanding Their Acquisition of English. Sociological Perspectives, 40(3), 429-455. http://dx.doi.org/10.2307/1389451

Park, R. E., \& Burgess, E. W. (1969). Introduction to the Science of Sociology. Chicago and London: The University of Chicago Press.

Pedraza, S. (2007). Transition and Emigration: Political Generations in Cuba. Retrieved from http://www.ascecuba.org/c/wp-content/uploads/2014/09/v18-pedraza.pdf

Portes, A. (1998). "Social Capital: Its origins and applications in modern sociology.” Annual Review of Sociology, 22, 1-24. http://dx.doi.org/10.1146/annurev.soc.24.1.1

Portes, A., \& Rumbaut, R. (1996). Immigrant America: A Portrait, second edition. Berkeley, CA: University of California Press.

Portes, A., \& Zhou, M. (1993). “The New Second Generation: Segmented Assimilation and Its Variants.” The Annuals of the American Academy of Political and Social Sciences, 530, 74-96. http://dx.doi.org/10.1177/0002716293530001006

Portes, A., Fernandez-Kelly, P., \& Haller, W.J. (2005). "Segmented assimilation on the ground: The new second generation in early adulthood." Ethnic and Racial Studies, 28(6). http://dx.doi.org/10.1080/01419870500224117

Rogers, A. (2000). A European Space for Transnationalism? Working paper series (ED. By A. Rogers). University of Oxford. Retrieved from http://www.transcomm.ox.ac.uk/workingpapers.htm

Rumbaut, R., \& Portes, A. (2001) Ethnicities: Children of immigrants in America. Berkeley: University of California Press.

Sanders, J., Nee, V., \& Sernau, S. (2002). Asian Immigrants' Reliance on Social Ties in a Multiethnic Labor Market. Social Forces, 81(1), 281-314. http://dx.doi.org/10.1353/sof.2002.0058

Tienda, M., \& Glass, J. (1985). "Household structure and labor force participation of Black, Hispanic, and White mothers." Demography, 22(3), 381-94. http://dx.doi.org/10.2307/2061067

Tienda, M., Donato, M., \& Cordero-Guzman, H. (1992). "Schooling, color, and labor force activity in women." Social Forces, 71(2), 365-395. http://dx.doi.org/10.1093/sf/71.2.365

Waldinger, R., \& Feliciano, C. (2004). "With the second generation experience 'downward assimilation'? Segmented assimilation reassessed.” Ethnic and Racial Studies, 27(3), 376-402. http://dx.doi.org/10.1080/01491987042000189196 
Waters, M. C. (1999). Black Identities: West Indian immigrant dreams and American realities. NY: Russell Sage Foundation

Xie, Y., \& Greenman, E. (2005). Segmented Assimilation Theory: A Reformulation and Empirical Test, Population Studies Center. University of Michigan.

Yinger, N.V. (2007). The Feminization of Migration: Limits of the Data: A Reformulation and Empirical Test, Population Studies Center, University of Michigan.

Zeng, Z., \& Xie, Y. (2004). Asian- Americans' Earnings Disadvantage Reexamined: The Role of Place of Education. American Journal of Sociology, 109, 1075-1108. http://dx.doi.org/10.1086/381914

Zhou, M., \& Bankston III. (1998). Growing American: How Vietnamese Children Adapt in the United States. NY: Russell Sage Foundation.

Zlonik, H. (2003). Migrants' Rights, Forced Migration Policy in Africa. Paper prepared for Conference on African Migration in Comparative Perspective.

\section{(cc) $\mathrm{EY}$}

This work is licensed under a Creative Commons Attribution 3.0 License. 